\title{
In the Fair Hearing Room: Resistance and Confrontation in the Welfare Bureaucracy
}

Vicki Lens

This article explores how welfare clients use and experience the fair hearing system, the administrative mechanism for challenging denials or reductions of aid in public welfare bureaucracies. Drawing on data from in-depth interviews with clients, it explores how old-style procedural protections like fair hearings are being used to challenge new-style welfare reforms. This research found that clients use fair hearings as a form of resistance and self-assertion, hoping that it will protect them from a bureaucracy perceived as arbitrary and capricious. Like many citizens, they are as concerned with being heard by their governmental institutions as they are with the outcome of their case and want to find within the machinery of government a forum where they can obtain recompense and respect. However, the legalistic and rule-bound nature of hearings makes it difficult for clients to present their claims, and meaningful participation is often denied them.

"There are two types of people. There's welfare people and there's regular people. You are now welfare people. You do as we say, you work when we say work, you don't have the privileges you used to have." These are the words of a welfare caseworker as reported by Laura, a fifty-six-year-old woman receiving public assistance. ${ }^{1}$ For Laura, and others like her, these words bluntly encapsulate the stigma, scrutiny, and control that characterize their daily interactions with the welfare system and which the Personal Responsibility

Vicki Lens is associate professor at the Columbia University School of Social Work. This study was supported by a grant from the Lois and Samuel Silberman Fund of the New York Community Trust. She can be contacted at VL2012@columbia.edu.

1. To protect the confidentiality of the participants, all names are pseudonyms. 
and Work Opportunity Reconciliation Act of 1996, referred to hereafter as welfare reform, solidified and expanded. In an act both symbolical and practical, the law declared that welfare was no longer an entitlement, while dramatically intensifying rules requiring work. Welfare reform thus completed and codified the evolution of welfare over the last few decades from a government guarantee of aid to government largesse granted only to those who can demonstrate their moral worthiness through work.

One of the few vestiges of the old system of rights is administrative "fair hearings," which can be initiated by clients to challenge denials, discontinuances, or reductions of aid. Scholars have criticized hearings in the past as ineffectually legalistic and rule-bound as the system, whose errors it was designed to correct (White 1990; Simon 1983; Mashaw 1973). Nonetheless it is one of the few spaces within the welfare system where clients can challenge the regime of rules under which they live. Through open-ended in-depth interviews with clients of a suburban welfare agency, this study explores what they think of the fair hearing system, how they make sense of it, and how they use it. It also examines how clients resist welfare reform's new commands, including its surveillance and control of their personal and work behavior, by using the bureaucracy's procedural mechanisms for challenging its worst excesses.

\section{THEORETICAL FRAMEWORK}

For the welfare poor "the law is all over" (Sarat 1990, 343). Welfare law and regulations control when and how welfare recipients' basic needs will be met. Need is determined by standardized mathematical formulas derived from the law, and the procedures for applying and receiving welfare are tightly scripted by legal rules and practices. Thus, while worker's exercise discretion alongside the law, the law guides much of what they do. Decisions that for others are private, such as when and where to work, and for how many hours each week, are controlled and circumscribed by the law. Thus, for welfare clients, the law looms large in everyday activities and decisions.

Law has been viewed as both protective and destructive to the poor. In the first three decades of Aid to Dependent Children (ADC), while rules guided the administration of benefits, the discretionary social work model was emphasized, and caseworkers had considerable latitude in parceling out benefits (Simon 1983). This approach was criticized in the 1960s as damaging, and even insulting, to the poor (Simon 1983; Bane and Ellwood 1994). It invited bias and prejudice, and subjected the poor to intrusive questions when they needed cash assistance, not social work. Influenced by the civil rights movement, which viewed law as a powerful and effective instrument of protection for disenfranchised groups, advocates argued that welfare recipients, no less than other citizens, should be protected by the law (Reich 
1964). ${ }^{2}$ Rules replaced more discretionary judgments, and individualized grants were supplanted by a uniform schedule. These rules, it was thought, would constrain worker bias and ensure fairness and equity.

With the greater emphasis on rules came a greater emphasis on legal mechanisms, such as fair hearings, to correct their misapplication. Advocates argued that the poor needed more powerful legal tools and procedures to challenge workers who misapplied the rules. Organizations, such as the National Welfare Rights Organization, also viewed hearings as a tactical tool for system-wide change (Kornbluh 2007). They encouraged the mass filing of appeals to disrupt the system and to publicize their demand for adequate welfare benefits. Activist lawyers turned to the courts to make hearings, which have been required by statute in some form since the ADC's inception in 1935, more accessible to clients.

A major victory occurred in 1970 when the Supreme Court in Goldberg v. Kelly (1970) held that hearings must be provided before the termination of benefits. The Court specified what such hearings should entail, importing many of the traditional features of rights-based procedural justice, including notice, an opportunity to be heard before a neutral decisionmaker, and the right to cross-examine witnesses. Consistent with a rights-based model, the response to a new welfare regime increasingly dominated by rules was more rules that curbed the bureaucracy's power by imposing procedural limitations.

The Kelly Court also recognized that "the opportunity to be heard must be tailored to the capacities and circumstances of those who are to be heard" (268-69). Scholars have questioned whether traditional procedural due process protections are effective for disenfranchised groups. White argues that while a hearing may provide "all the rituals of due process" $(1990,32)$, it does little to alter welfare's substantive terms, leaving clients economically vulnerable and hence hesitant to complain because they fear retaliation. The suspicion that hovers over welfare recipients makes silence and discreetness more likely than complaining (see also Gilliom 2001; Handler 1986; Soss 2002). According to White, those who do speak up will not be heard, because their stories are at odds with a bureaucracy that has reduced complex human needs to a legalistic formula. Hearings demand administrative and legal specificity, leaving little room for clients' pleas and the realities of their lives. Clients are more likely to give a relational account that emphasizes social need and entitlement, rather than the preferred rule-orientated account (Conley and O'Barr 1990). In short, procedural justice means more than having an opportunity to speak, but also to be understood, which fair hearings cannot ensure.

2. It was not only liberals who argued for the change. Conservatives argued that rules and standardized formulas would make it more difficult for caseworkers to provide generous benefits (Bane and Ellwood 1994). 
Bumiller (1987), in her study of victims of discrimination, echoes these concerns, noting that legal channels for resolving complaints are often avoided by victims. Some refuse to define the problem as legal, instead blaming themselves, or viewing it as an experience to survive and not a legal problem to resolve. Complaining risks making things worse or not any better. It means accepting the label of victim, thus reproducing, in a legal forum, feelings of powerlessness and isolation. As in the welfare context, legal forums replicate asymmetrical power relationships rather than leveling them.

Sarat stresses that there are spaces within the law that can be used to resist it. In describing the legal consciousness of the welfare poor based on interviews with clients who had sought legal assistance for their welfare problems, Sarat illustrates how clients learn to assert their needs despite their powerlessness. Clients play with the rules, using their insider knowledge of the system to resist the unreasonable and the arbitrary. Clients use the law, and legal assistance, as a "way of individualizing and humanizing the welfare bureaucracy" (Sarat 1990, 363). Asserting a complaint is not just a legal act but a willing of visibility. It is a way of exposing the irrationality of a rationally ordered bureaucracy whose purpose is to help but which frequently fails to do so.

For the marginalized and the powerlessness, "standing against the law" is a way to overcome its power, if even just a bit (Ewick and Silbey 1998, 165). As Ewick and Sibley describe, while this sometimes may mean laying low, and trying to avoid the law's grasp, it often means engaging and subverting the bureaucratic structures in which public power is ensconced. It is an unscripted resistance that takes advantage of leaks in the organizational structure. It employs its tools against it, for example exposing the bureaucracy's failure to follow its own rules or looking for cracks within the rules. Sometimes the resistance can take on a decidedly overt tone. Instead of avoiding conflict, resisters may generate complaints, "leapfrogging over layers of the bureaucratic hierarchy" (211) so as to subvert that hierarchy, "converting [complaints] from an individual into an organizational problem" (213).

For welfare recipients, the need to resist, and complain, has grown even stronger. As Sarat noted in 1990, "During the last decade welfare eligibility standards have been made more stringent, and a continuous process of reporting and review was put into place. Law's hard, bureaucratic face has supplemented, if not altogether replaced, its right-protecting concerns" (344). Welfare reform legislation, passed six years after Sarat's observation, has completed the transformation, officially signaling that the era of rights is over. Subject now to an all-enveloping system that monitors their personal behavior, clients still have some remnants of that system, notably fair hearings, at their disposal. ${ }^{3}$

3. States are still required "to provide opportunities for recipients who have been adversely affected to be heard in a state administrative proceeding" (42 U.S.C. Sec. 402). Moreover, despite statutory language eliminating welfare as an entitlement, recipients may still retain a property interest in welfare, and hence hearings may be constitutionally required as well (Scanlan 1998). 
Although fair hearings are a fixed feature of the welfare bureaucracy, few studies have explored clients' experiences at fair hearings, either before or after welfare reform. Earlier studies, conducted during the era of Kelly, were primarily quantitative, focusing on appeal rates and outcomes (see Hammer and Hartley 1978; Baum 1974; Handler 1969; Bell and Norvell 1967). White (1990) and Miller and Holstein (1996) are among the few scholars who have explored fair hearings qualitatively: White through relating the story of Mrs. G., a client she represented at a fair hearing, and Miller and Holstein through an ethnographic field study of dispute processing in the now defunct Work Incentive Program. Thus, there is very little empirical data on clients' actual experiences with the fair hearing system and none at all on how old-style procedural protections like fair hearings are being used to challenge new-style welfare reforms. This study attempts to fill that gap.

\section{RESEARCH DESIGN}

This study is part of a larger study that explored the emergence (or nonemergence) of formal disputes in welfare bureaucracies through qualitative semistructured interviews with clients who had been sanctioned for violating work rules. ${ }^{4}$ The original study examined what motivates or inhibits clients from appealing adverse agency actions. Two groups of clients were interviewed: those who had appealed their sanction through the fair hearing system, and those who had not. In all, thirty-four clients were interviewed. The focus of this article is on the twenty clients who chose to challenge the welfare system through fair hearings.

Initial field research focused on sanctioned clients, because sanctions embody a particularly punitive aspect of welfare reform that starkly highlights issues of power and resistance. Unlike other kinds of less visible or traceable bureaucratic actions, sanctions are direct and blunt. They provide fertile ground for exploring how fair hearings are being used in the context of welfare reform's harsher features. In the course of field work, it became clear that clients' fair hearing use is fluid and complex; the same client who failed to appeal a sanction would readily appeal other adverse actions. The study was expanded to explore this and to provide contrasting stories of resistance beyond sanctions. Thus, additional clients were recruited during the study who used the fair hearing system other than for appealing sanctions.

4. Sanctions are financial penalties imposed on clients who violate the work rules. The penalties range from a partial reduction to a total loss of the grant, depending on the state. In New York, sanctions result in a grant reduction equal to the sanctioned individual's pro rata share. The first noncompliance results in a one-month grant reduction, and the second and third result in three and six months, respectively. For a full discussion of sanctions under welfare reform, see Lens 2006. 


\section{LAW \& SOCIAL INQUIRY}

An exploratory qualitative research design was used, because, as noted above, there is very little empirical data on clients' actual experiences with the fair hearing system. In-depth interviews were chosen, because they allowed clients to use their own words to emphasize what aspects of their experience were most important to them.

Clients were drawn from a public welfare agency in Suffolk County, New York, a suburban county located in the metropolitan area surrounding New York City. Clients were recruited through the county's primary legal services office for low-income clients and through various social service agencies that provided housing, employment, and crisis intervention services. Referrals were also made by a nonprofit agency that had a contract with the local Department of Social Services (DSS) to assist sanctioned clients in Suffolk County to come into compliance with the work rules. Recruitment flyers were also distributed at various other social service agencies located throughout Suffolk County. Finally, clients who participated in the study recruited family and friends. Of the twenty clients interviewed, ten were African American, eight were white, and two were Hispanic. The average age was thirty-eight. Fifteen of the clients had families with children, and five were single or married couples with no children. ${ }^{5}$

All but two of the clients were interviewed in their homes to ensure privacy and confidentiality and to create a more relaxed environment conducive to in-depth interviewing. ${ }^{6}$ Interviews lasted approximately an hour and a half and clients were paid $\$ 25.00$ for their participation. All of the clients agreed to be tape recorded. Clients were asked a series of open-ended questions that explored their general experiences with applying for and receiving welfare, the particular incident that generated their request for a fair hearing, and their perceptions and experiences of the fair hearing system. To get as broad a view as possible of clients' views of the system and their place in it, clients were also asked about welfare reform and welfare policy in general.

Each interview was transcribed verbatim. Data analysis began with a review of each transcript as a whole. On the first read, I identified major themes and noted them in the margins of the pages. I then used Hyperresearch, a computer software program designed for the analysis of qualitative data, to code each transcript. I began with an open-coding approach, first locating descriptive themes (Strauss 1987). After coding each transcript, I generated a copy of the coded excerpts, reread and recoded it, grouping descriptive themes into clusters, and identifying overarching themes within a single case (Miles and Huberman 1984). After coding all of the transcripts, I reduced

5. In New York State, single and/or childless adults are eligible for public assistance under the state's safety net program.

6. These clients were interviewed in the offices of the nonprofit housing agency that recruited the clients for the study. 
the codes into thematic clusters and compiled in one place the excerpts across cases that reflected these major themes. To make sure that I had preserved the context appropriately, I then reread each transcript and prepared a several-page summary that included a synopsis of key events and selected excerpts that best reflected the major themes I had identified. I also looked to see if the themes identified in individual cases and across cases matched the patterns I expected to find based on the literature review. Thus, coding was a recursive process, where I moved back and forth from an inductive to a deductive approach and from segmented descriptive codes to major overarching themes both within a single case and across cases.

\section{Limitations}

One limitation of this study, shared with all qualitative studies, is that by their very nature, they are primarily limited to the sites being studied. This study is limited to the fair hearing system in one county in New York State. Its applicability to other counties within the state is limited. Although the state administers the fair hearing system, individual county practices regarding fair hearings vary; thus fair hearings are not uniform across the state. On the other hand, this study also took place in a county similar to other counties outside New York City, where 75 percent of clients who proceed to a hearing lose (Lens 2005). It thus offers some insights into clients' experiences with a system that rarely provides the relief they are seeking and, which may hence be applicable to other counties with similar low success rates. Its applicability to other states is limited, as there are wide variations among states in the use of hearings (Lens 2005).

\section{Findings}

Of initial interest is why clients use the fair hearing system. As studies from past decades have demonstrated, appealing is a rare act, with less than 1 percent of clients appealing, although appeal rates have reached as high as 10 or even 20 percent in certain urban areas (Hammer and Hartley 1978; Baum 1974; Handler 1969; Bell and Norvell 1967). The most recent study of appeal rates based on state administrative data, conducted by this author, found rates still in the 1 percent or less range, but also higher (6.8 percent) in urban areas, such as New York City (Lens 2005). Thus, for the vast majority of clients, the fair hearing system remains an unused and perhaps not thought of bureaucratic option.

While this researcher (forthcoming) has in previous publications explored why clients do not appeal, some discussion of this here provides a helpful contrast to why some do. Most clients who do not appeal express a profound 
skepticism that fair hearings would not be any different, in form and substance, from their ongoing and negative interactions with caseworkers. They view hearings as an extension of the agency, not an instrument for challenging it. As noted above, a rights-based model of law rarely puts victims on an equal footing with their powerful adversaries (Bumiller 1987; White 1990). Thus, the powerlessness, silencing, and subordination that characterize their everyday interactions with the bureaucracy would, they believe, only be replicated in the fair hearing room. And unlike most of the rules surrounding and controlling clients, fair hearings are voluntary. Avoiding them is thus common sense.

The subsample of clients who did appeal, and reported about here, put more stock in fair hearings, viewing them as a way to break their subordination and silence, or to short-circuit or resist the rules. Unlike those who did not appeal, they had adapted different strategies for surviving the bureaucracy that incorporated fair hearings. Despite a common perception that welfare clients are more alike than unlike, those strategies varied among even this subgroup, and exhibited subtle and not-so-subtle differences in legal consciousness. ${ }^{7}$ For some, fair hearings were used as a way to emphasize need over rules; for others fair hearings were a piece in a game played to outwit the welfare bureaucracy. For still others, fair hearings were a tool of resistance, often played like a game, but more rebelliously. For nearly all of the clients, including the very few who were successful, fair hearings were often a trying and negative experience, much like their experiences with welfare itself. ${ }^{8}$ Yet, despite this, they persisted with their claims.

\section{PLEADING NEED OVER RULES}

For several clients, fair hearings were used to assert needs that had been denied or ignored. Ellen, who was interviewed prior to her hearing, is an example. Like virtually every client interviewed, she was acutely attuned to the degradation and stigmatization common in welfare bureaucracies (Anderson, Halter, and Gryzlak 2004; Miller 2003; Soss 2002). When asked

7. Legal consciousness is how people experience the law, or "how law constitutes everyday life and its common problems" (Marshall and Barclay 2003, 619). Instead of an instrumental approach that examines laws affects on individuals behavior, legal consciousness studies examine how "people come to terms with use, or ignore law as they construct their own local universe of legal values and behavior" (Sarat and Kearns 1998, 60). This study falls squarely in the tradition of legal consciousness studies by exploring, through their own words, how welfare recipients use, think of, and view the fair hearing system in their everyday transactions with the welfare bureaucracy.

8. The exact percentage of hearings won by clients could not be calculated, as several clients had multiple hearings over the years, the outcomes of which they could not always clearly recall, or which they did not know at the time of the interview. Overall, and consistent with the low success rate in Suffolk County, most of the clients reported unfavorable outcomes. 
how she was treated at the agency, she responded "like I was the bottom of the food chain." She described her first interview for aid, when she was nineteen, pregnant, and homeless as "horrible ... I'm surprised they didn't take a sample of my blood. I mean they basically want every single thing."

Controlled and hemmed in by the rules, Ellen was equally wary of what she called the "guidelines" or individual worker's discretion. It was the "guidelines" she explained, but not a rule, which required her to have three different forms to prove a fact of eligibility, while eligibility itself was determined by a rule. And it was the "guidelines" that made it possible for her worker to send her "to emergency housing somewhere where there's crack heads, and prostitutes, and not a good environment for a pregnant person ... like a church organization, or a shelter for girls."

However, despite her evident frustration with both the rules and their discretionary application, Ellen saw fair hearings as a recourse when she was discontinued from aid because of "excess income." She was cut off from benefits when she obtained a job that put her above the agency's financial eligibility level. She did not earn enough to pay her expenses, including her rent and the daycare she needed to work. If she worked a few hours less a week, or for less money, she would have remained eligible for crucial benefits, including child care, health care, and a rent subsidy. To Ellen this made no sense; she wanted to work, and the agency wanted her, and even required her, to work. Ellen construed the agency's decision not as a neutral act, but more personally. As Ellen explained, the agency "wanted her to stay at poverty. ... They want you to stay, when you're not going anywhere. And that's not me. I'm twenty-two, I'm still young. I've got the opportunity to make all my dreams come true.... They seem like they've got too much control over my life."

Ellen believed that the hearing officer had the power to exempt her from the rules, particularly because she was trying so hard to play by them and become self-sufficient. Here she describes how she will approach the fair hearing and what she hopes will happen:

Ellen: I'm just gonna explain to them, I have all the paperwork that they sent me in the mail, I have all my pay stubs that I got from my last job and I'm just gonna explain to them, I'm like, "this is ridiculous, I'm working, doing what I got to do," and I'm gonna give them a breakdown, I don't care if you count before taxes, this is how much I was bringing home a week, this is how much I made in that month that I was working there. How was I supposed to pay this, this, this, this, this and this off of that salary?

Interviewer: What do you expect to happen when you tell them this at the hearing?

9. Some quotations were edited for brevity and readability. 
Ellen: I'm expecting them, hopefully in my situation they can, should be able to do a case-by-case basis, instead of having guidelines and rules for everyone, like everyone's in the same situation. I feel in my, in my case, they should make an-you know, it different for me, "Okay, if you're making $\$ 10.00$ an hour, you don't have to pay all your rent, pay half, we'll still pay your child care for six months until you can save your money." Or something like that, like give me a little help, don't just cut me off so I have to go back on it again. I'm trying to get off of it, you should continue to give me that help to get off of it, instead of having to fall back on it.

For Ellen, the hearing room was a space where she would explain the realties of her life, backed up with written documentation ("I have all the paperwork ... I have all my pay stubs") that she knows are the currency of the bureaucracy. She reified the fair hearing officer, imbuing her with the power to disregard the rules, and hear her directly, without the rule's mediating influence. She would appeal not to law but to common sense: "you should continue to give me that help to get off of it, instead of having to fall back on it." She would even negotiate a bit, limiting her plea for help: "for six months until [I] can save [my] money." If she explained all this, she thought, an exception could be made for her-her individual needs recognized.

As Sarat observed, for some clients, getting legal assistance for their problems with welfare is a way of being noticed and heard. For Ellen, hearings, like legal assistance, served a similar function. She used her "opportunity to be heard" to go beyond the procedural and substantive confines of the law. Instead she reached around the law to make a rational appeal based on the moral force of her need (Sarat 1990; White 1990).

\section{Playing the Game}

Several clients worked with the law instead of around it, viewing hearings as a tactical encounter where the agency could sometimes be outwitted. As Ewick and Sibley (1998) describe, even in a rule-bound bureaucracy, legality can be experienced as a game, as individuals search for ways to use the law to assert their needs. Law is always shadowing them but so too is the possibility that it can be outfoxed or outmaneuvered. Insider knowledge, energy, and skill can be used to bend it to their needs. Carol was one such client. Employed for years as a paralegal before a job layoff led to homelessness and then welfare, Carol transferred her knowledge of the law and legal systems to the welfare center. Sanctioned repeatedly by the agency for failing to comply with the work rules, Carol played the game so well that when she walked into the hearing room, 
the agency representative would routinely agree to settle the case in her favor.

It had become so repetitious that the third time, the third time or the fourth time when I walked into the hearing it was like, I know the hearing examiner now. No really, it's like, you know, I don't get into a debate with the person-with the representative from social services because I know her as well. You know and she has a big stack of papers and she says “you know, right, what's your story?" You know recorder off whatever, what's your story. And she goes out and she makes a call she comes back she says "alright forget it, we don't even have to go through with this."

According to Carol, she is treated less like a welfare client than an experienced and respected negotiator. She is familiar with all of the players ("I know the hearing examiner.... the representative from social services because I know her well"), and is treated credibly and respectfully by her adversaries: She "doesn't get into a debate with them," they just turn the recorder off (all hearings are taped), ask her for "her story," and then settle it. She attributes her wins not to knowledge of the law but to common sense: "I've won every fair hearing, you know it's solely based on how much knowledge you have. Not how much knowledge you have in regards to the program, but just it's common sense." In other words it's her tactical skills, not substantive knowledge, which explains her success.

Carol's ability to level the playing field was unusual. While other clients also portrayed hearings as skirmishes in a game, most were not as successful. Linda was one such example. She depicted herself, and other clients, as insiders who know the rules of the game. As she explained, workers "can't break the guidelines," because "they'll get reprimanded" but that:

Most people who get on social services, not a lot of them, but most people who get on social services already know what they're dealing with, what the guidelines are, what they're entitled to. If they find a loophole somewhere in that guideline, maybe they're entitled to more, and if you find out you're entitled to more than what you've been getting, you can take them to a fair hearing and you can get more.

Linda described fair hearings as a powerful tool: "It gives you a voice. It does give you a voice." Revealing her game strategy, she explained that she never notified the agency she was appealing "because why would I give them a chance to dig up a case on me?" But Linda was always outwitted and lost every hearing. She wasn't sure that she would ask for another one and hadn't appealed her most recent sanction. If she did, she was "gonna have my cards more stacked up before I just take them." Thus, Linda knew she was being outmaneuvered, and the game strategy was wearing thin. Her search for loopholes appeared more a hope than a reality. 


\section{Resisting the Bureaucracy}

Several clients, while incorporating aspects of game strategy, used fair hearings in a deeper, more subversive way. They "stood against the law" looking for ways to resist it (Ewick and Sibley 1998, 165). In a bureaucracy, this may involve turning the tables and invoking the bureaucracy's own rules against itself by vigilantly monitoring its actions and highlighting its failings.

Barbara typifies such a client, requesting fair hearings when she thought the agency wasn't following its own rules or wasn't sufficiently attuned to her needs. She challenged both the agency's rules and the agency's discretion. Thus, she challenged the amount she was required to pay toward emergency shelter, the agency's failure to pay the storage fees for her belongings when she was in the shelter, and the agency's decision to move her to a shelter far from her job. When the agency moved too slowly in complying with a favorable decision, she brandished it before her workers, threatening "to sue" again if they didn't comply. Barbara clearly relished putting the agency on the defensive.

However, Barbara did not use hearings to challenge her many work sanctions. While she firmly believed the agency wrongfully sanctioned her for not attending a work meeting because her son was ill, and even filed for a fair hearing, she decided not to go, because she thought she had no chance of winning. Explaining that she didn't have a doctor's note to prove her son's illness because he wasn't ill enough, nor did she have the money to take him to the doctor, she "just got discouraged because I was like, well, I didn't have no excuse, your kid could be dying, and they wouldn't care, you know."

To Barbara, hearings were a selectively employed tactical tool primarily useful for challenging those rules that did not implicate her behavior or moral worth. Viewed by the agency as a bad parent and a bad worker, she laid low and "lumped it" when she was sanctioned for work rule violations. She was convinced she could never marshal the proof needed to overcome the agency's negative judgments. But when she could turn the agency's rules on them, and expose their errors instead of her own, she fought back. Thus, Barbara carefully calculated her chances of winning before requesting a fair hearing, firmly drawing a line at those offenses where her behavior was suspect and the bar of proof too high. She looked for spaces of resistance within the rules, finding them only when she could shift the focus to the agency's behavior instead of her own. To protect herself, and typical of other clients interviewed, Barbara both resisted and retreated, using fair hearings offensively, but never defensively, and calling the agency to account only when there would be no accounting of her actions.

In sum, appealing served varied interests for clients. It was a form of resistance and a way to challenge power. It was an act of self-assertion or a display of prowess. However, as described next, more often than not, the 
actual fair hearing experience was often far different from what clients anticipated.

\section{IN THE HEARING ROOM}

Hearings took place in a small ordinary room within the welfare center. The room had none of the physical flourishes or embellishments that signal the solemnity of the law or justice in a courtroom. The parties sat around a table, with the hearing officer at the head, and the client and a representative of the agency flanking him or her on either side. The only physical manifestation of any formality was a tape recorder placed on the table, used to record the hearing. The worker who made the decision was not routinely present; instead an agency representative, assigned full-time to hearings, presented the evidence and questioned the client.

The hearings followed the prescriptions of procedural due process. The hearing officer was designated by the state as a neutral independent decisionmaker who was not involved in the original decision. Both the agency representative and client were entitled to present evidence, oral and written, and to confront each other. Formal rules of evidence applied, albeit loosely. (For example, certain evidence, such as hearsay, not admissible in court was permitted.) However, despite these trappings, hearings followed a bureaucratic logic or rigidity that diminished these procedural protections and left clients feeling that they had not been adequately heard or fairly judged.

\section{The Decision Maker}

Procedural due process commands a neutral and unbiased decision maker. The decision maker in the fair hearing system is the state agency, which provides regulatory and supervisory oversight over local county agencies that administer the program and provide aid to individual clients. Thus, although the state and local welfare agencies are distinct entities, they are intertwined. While the state, and, by extension, the hearing officer, are not the officials who makes the initial individual case decisions, they promulgate the laws and administrative directives that the local agency must follow.

To many clients, the difference between the state and local agency was a difference without distinction. Pam complained that "it was just all social services, there's nobody there outside of social services. No D.A., no District Attorney for the State of New York or nothing like that, it's just all Department of Social Services that does the fair hearing, which is not right." She referred to the hearing officer as "the advocate from the DSS from upstate New York" (where the state agency has its office), thus rejecting any semblance of neutrality (emphasis supplied). Laura echoed her complaint: "I still can't 
believe the judge is, is impartial. He don't come from the streets like us, he comes from the state. He works for the state. You can tell he's not really on our side." Cindy made it equally as clear that she didn't think the hearing officer was unbiased: "Because you're for social services. You're not for the people. So I don't really know what kind of judge you are, I think you're a social services judge, or a state judge, to be able to keep contributions of the state, in the state."

As Soss observes, welfare recipients "tend to see government as one big system" (2005, 323), and the lessons they learn about one part of government influence how they think about government, and the political system, in general. Soss was speaking about clients' broader beliefs about political participation, but his observation is equally as applicable here. To Pam and Cindy, there is no distinction between the state and local social services agencies; they are all social services.

Cindy and Laura make a further distinction: between government and the governed. The state is not "for the people"; they "are for social services." "He doesn't come from the streets, he comes from the state." What they mean is that individual interests are often different than government interests. The state, as Cindy puts it, wants to "keep contributions in the state." As she later clarifies, they "have a quota of people to cut, and a quota of people to put on." In other words, the state's interest in protecting fiscal funds conflicts with individual citizens' claims on those funds. Thus, to Cindy and Laura, having the state social services department hear their claims is inherently biased.

Pam makes another distinction when she complains that there was no "District Attorney for the State of New York" at the hearing but "just all the Department of Social Services." Like Cindy and Laura, she questions how the same system that cut her benefits can fairly hear her claim. But unlike Cindy and Laura, she accepts the role of the state in her dispute against the state. Her choice of the District Attorney, albeit an inappropriate entity to hear her claim, is revealing. She suggests the separate and independent state actor whose job is to prosecute wrongdoing by citizens. By placing the welfare department on equal footing with other individuals who may have broken the law, she is trying to reduce its power. She cuts it down to size, calling in law enforcement, the most visible manifestation of government power, to rule on its actions. Only then would the hearing be fair.

Thus, clients were often suspicious of the state hearing officer, viewing him or her as an adversary or not neutral. What they observed in the hearing room further enforced the view, as Barbara put it, that the state "side[s] together" with the local welfare center. Linda, for example, picked up on the easy familiarity between the hearing officer and agency representative when she walked into the hearing room:

They're calling each other by first names, they're laughing. I'm nervous, you know, I'm not in this atmosphere as they are. Honestly, I'm the 
enemy and they're the-they're friends. ... You feel the tension, yeah. And then when I come in, then they, "alright, we're here on the case of Miss R. versus the Department of Soc"-you know and it's like, oh I know I'm gonna lose-Because they know each other! I mean, if it's, it's like if you go into a courtroom to defend yourself and you see the prosecutor and the judge just talking, and they're laughing and giggling and stuff, and then when you come in, "alright."

Clients' sense of themselves as outsiders, or as Linda dramatically put it, "the enemy," was not dispelled by the semiformality of the hearing room. Linda saw such due process procedures as tape recording as false formalities, noting that Albany (where the state has its offices) "can't see beforehand all their talking, they don't have a record then." Pam echoed her concern that it was all a show: "They were just honoring the fair hearing because they had to, because I requested it, because they knew they were still gonna do the same thing no matter what I said."

The hearing itself often became a forum for interrogating clients, even though it was the client who had requested the hearing to challenge the agency's allegedly wrongful actions. Clients' motives and actions, not the welfare agency's, were suspect. Instead of commanding and refereeing the hearing, the hearing officer remained a muted presence, or as Carol described her hearing officer, he was "tired, he's actually very tired, he's very nice, but he's just tired." Many clients had no vivid memories of the hearing officer, in contrast to the agency representative, who loomed large in clients' recalls of their hearings. Clients' portrayals of the agency representative were nearly identical as demonstrated by the following excerpts:

Carol: Just is rude, just out-and-out rude, a really nasty old lady.

Mary: Rude! They were horrible. And if you like, don't remember, there's something wrong with you.

Laura: They get angry there, they get indignant, Social Services, they jump up out of their chair and they're, God, you know-ooooh-you have to see it to believe it.

Ann: The hearing rep from Social Service she was a snob, a totalshe was just, she was totally rude, she was just like, she would keep asking me the same question, like I wasn't—as if I wasn't answering, and I'm still explaining the same thing over and over and over and over, I'd tell her again and she'd still ask me the same question.

Amy: The social service representative seemed, I don't know, she seemed like, I don't know what's the word for it, like, "you're wrong and I'm right 'cause I'm the state." 
Thus, many clients experienced hearings as a replay of their interactions with their caseworkers. The hearing officer's passivity left the agency free rein to replicate the silencing and subordination that characterized clients' daily contact with the agency. They questioned whether their stories were heard or their actions fairly judged. In short, clients did not perceive hearings as a neutral forum nor the hearing officer as a neutral decision maker. They viewed hearings as a gesture without substance, an empty and futile exercise rather than a forum for asserting their claims.

\section{Presenting Evidence}

Documentation, or the reduction of every transaction into a written form that stands for the actual event, is the sine qua non of bureaucracies (Miller and Holstein 1996). Writings take on a rarified role in a bureaucracy. They are imbued with a misplaced objectivity and solidity when in actuality they are "partisan accounts that express and obscure the interests of those who construct and use them" (9). Their existence puts clients at a distinct disadvantage. First, they must overcome this reification of documents, their status as unassailable fact. Then clients must be able to gather their own written and credible version of events.

Most clients learned early on that paper was the coin of the bureaucracy and that the existence or absence of a particular paper could have disastrous consequences. They often constructed parallel files at home and hoarded them as a talisman. Ellen kept every notice she was sent about the work rules, explaining, "I've got so much paper that I hold onto so they can't get me." Alice protected herself from claims she didn't submit the right documentation by making a copy of everything she sent to the agency. When the agency failed to provide her with the proper instructions on how to handle her utility bill, Mary brought down her entire folder to the agency as proof: "And you saw how organized I was, lady. I had this whole folder, with everything. I said, 'Ok you tell me, where's the paper that I'm supposed to have.'”

Most clients however were unprepared for hearings and reacted almost viscerally to the sheer weight of bureaucratic paperwork at hearings. As Linda described it: "And they bring out this big file with all, and they just have all this documentation, documentation, over my little letter" (emphasis supplied). Despite their efforts, clients, unlike workers, are not used to documenting every interaction. They also have less access to the types of proof that are valued. Clients also virtually always are held to a higher standard of credibility; they are assumed wrong and the agency assumed right. As Katie describes, "they [the agency] can have nothing either, but they'll take their words over yours." Proving the agency is wrong is extremely difficult. As Laura described it, "that's almost like suing a doctor ... that's pretty hard to say the agency did wrong." 
Ann's fair hearing case is illustrative. Ann was sanctioned when a worker at her job site confused her with another client and reported her absent. ${ }^{10}$ Ann knew it was a case of mistaken identity, because the worker told the agency that Ann's excuse for not attending was that she had to take a medical assistant's test. But Ann, who was a certified nursing assistant, was never enrolled in a medical assistant program and hence had no such test to take. The job site worker even admitted she may have confused clients, telling Ann "I get so many different girls . . . I get so many different girls, um I didn't know who was who." At the hearing, the agency submitted a written summary of the agency's conversation with this same job site worker indicating Ann had been absent. Ann tries to argue, unsuccessfully, with the fair hearing representative that her report of her conversation with the job site worker is as acceptable as the agency's:

She [the fair hearing representative] said something to me about what the lady at, at the center said to her. I said well, "how do you know that that's a true statement? How do you know she was talking about me? Just like, if I said to you that she told me something, you're telling me that she told you something, okay, but what she told you you're believing, why wouldn't it be possible for her to tell me something also." (Agency representative): "Well you don't have that in writing" (emphasis supplied). "She didn't give you anything in writing either. You wrote down what she said. ..." And I said "Well, if I would have-if I would have wrote it down, what she said to me, would that have been evidence?"

By asking "If I would have wrote it down what she said to me, would that have been evidence," Ann is arguing that her word is as good as the agency; the only distinction is that one is written and the other verbal. But the evidence Ann and the agency representative can produce are not equal. Unlike Ann's verbal account, the agency's version was written and preserved in a bureaucratic file, transforming a questionable account into objective fact that Ann could not counter with her words. Even if Ann created her own written record of her conversation with the job site worker, it would still not equal the agency's. It is not the official bureaucratically produced version, it is only Ann's.

Ann also did not have access to the same proof as the agency. Ann was not able to demand from the job site worker that she put into writing her verbal admission; the worker refused to do it. It would have required her to contradict the earlier version she had provided to the agency and would be a serious breach of established bureaucratic pathways for constructing the facts. The job site worker and the agency, without Ann's input, had already constructed the agency's version of the events. Although the case

10. To comply with the work rules, clients who do not have private sector jobs are assigned to various public and private nonprofit agencies, where they work off their grant. 
was about her, Ann was treated as an interloper operating outside established agency channels.

The agency's resistance to altering their established truth persisted even when Ann pointed out that her own case file contained corroboration of her version. As she explained, if she had been enrolled in a medical assistant class, it would have been paid for by the agency and hence recorded in her case record. If there were no such record in the file, it would confirm that the worker had confused her with another client. However, the agency had no reason to search their own records for any inconsistencies or proof that would refute the official and established version of the facts. To do so would only expose the unreliability of their own records and the fallibility of the bureaucratic process that constructed them. It was up to Ann, not the agency, to prove their mistake, which she was ill equipped to do.

Some clients, like Mary, had a different, but related problem, with proof. For them it was hard translating the facts of everyday life into a form of proof acceptable to the bureaucracy. Mary had worked for seventeen years doing secretarial work at an oil company but was now unable to work more than three hours a day because of a herniated disc and other medical problems. She viewed herself as willing, but unable, to work: "You know I'd love to work full-time again. I don't have a baby at home no more. . . I could do whatever I want. I don't want to stay home 24/7 either." But the agency determined that she was not disabled and was able to fully comply with the work rules. Since her doctor had confirmed her disability to the agency, she was mystified when they told her she didn't have the proper notes. "They said I have nothing new. I said 'well I really didn't think I needed anything new.' I said 'you see all my limitations, you know.' "

Mary's belief that she "didn't think I needed anything new" and that the "agency could see all my limitations" convinced her that she didn't even need a lawyer at her hearing: "I thought I had enough paperwork.... Doctor's, MRI's, doctor's letters stating that I had a herniated disc." At the hearing she is confronted by a skeptical agency representative:

I mean I felt like she was, just intimidating me, like telling me I was a liar. In other words, yes, I came home I said, "I just got called a liar" —what am I, a liar?! What is this, you know? I said, "I'm telling you the truth, I'm telling you what I know, and who I am and what is going on."

She pleads with the agency to tell her what she is missing:

What else do you want from me? What do you want? Somebody tell me, what kind of paperwork?... Or tell me more of what I need to make this work, you know, what can give me actually a fair hearing? 'Cause I didn't have no fair hearing, I'm sorry, I didn't feel I did. Tell me what I need to have more of a fair hearing. You know, how much 
more paperwork-or send me proper paperwork that will answer your questions.

Mary later discovers, after she lost the fair hearing, the "proper paperwork":

Like I did this time, they got me decent papers, the doctor had to fill out exactly everything what I can do. And I think this is gonna help because like, social services will send you paperwork? Limitations, now I'm gonna write them down. That's all they ask for is for you to write them down. And um, I wrote 'em down, and now this time the doctor wrote everything and he wrote the same answers, so this should help. Okay, but now why didn't you tell me, why couldn't I have done that?

Mary begins the process by believing her workers can "see all my limitations." To her, the facts of her life are in plain sight and she doesn't need a lawyer to explain them. She is shocked at the hearing that she is not believed, that her doctor's note confirming her medical problems and her own description is not enough. She is telling them the "truth": "I'm telling you what I know, and who I am and what is going on." She experiences the agency's skepticism as a personal attack: "I was called a liar." She realizes she is going about it all wrong, and that what she needs is the right "paperwork." She gets some "decent papers" from the same doctor who provided her with the note but which now invokes the exact and precise bureaucratic language required: "limitations." Her everyday meaning of the word "limitations" was now transposed into its technical, bureaucratic definition. Mary's disability has not changed, but the manner in which she describes it has. She had learned to speak the language of the bureaucracy rather than her own.

Fitting their stories into the narrow and legalistic culture of the bureaucracy was a common problem for clients. The laws that govern aid are often reductive and rigid. Under welfare reform, these simplistic rules are now routinely used to evaluate and monitor clients' behavior and worthiness. Not only are the rules too blunt and rough to judge behavior, they also permit judgments based on only a slice of it. A single missed appointment among the many appointments clients attend could result in the denial of aid. Thus, not surprisingly, clients who ran afoul of the rules and knew their worthiness as clients was being judged, saw hearings as an opportunity to prove their worth. This meant telling a different story than the hearing officer wanted to hear. In short, hearing officers and clients often had a different definition of relevancy.

This is illustrated by Cindy, who had been denied aid because she failed to attend a Front End Detection System (FEDS) appointment, required by the agency to detect and prevent fraud. Recently released from the hospital after stomach surgery, Cindy's FEDS appointment conflicted with a doctor's appointment to get her surgery staples removed. Although she called and rescheduled the FEDS appointment for the next day, when she came for 
her appointment, she was told she was sanctioned for missing the appointment the day before. At her hearing appealing this determination, Cindy knows that underlying the decision is the agency's view that she is irresponsible. She tries to explain why she is a "good" client but is cut off by the hearing officer:

He just said "keep it simple." I guess my answers were too long. Because I wanted him to really understand why, it wasn't like I'm just this couch potato that does not feel like-I'm not responsible. I mean even before this if you go - and I said to him, I even have papers of that, I said "if you go back, I've been off of social services. I went back to work and the whole bit. I went to school through social services and so on and so forth. I was able to support my family but then I became ill. Um, I had an operation." And he said, "can you keep it simple?" And I said, "But I'm trying to explain to you how this even all came about."

Cindy describes what keeping it simple means: "very blunt answers, either yes you made the appointment, no you did not make the appointment, well why didn't you make the appointment?" She responds:

I had an operation, I'm still ill right now. ... I couldn't come because I had to have staples removed. He said to me, "and you couldn't change that appointment?" I said, "Would you?" And then he just said, "Okay, that'll be it." I said, "You don't need anything?" "No."

Cindy wants to be judged by the whole of her life, not the single missed appointment. When she says "I'm trying to explain to you how this even all came about," she means her becoming a welfare recipient, not just the missed appointment. She knows her status as a welfare client implicates her moral worth. Thus, Cindy wants the hearing officer to know that she is not a "couch potato" but a responsible person who went to school, worked, and raised a family until she became ill. But the hearing officer cuts her off, tells her "to keep it simple." Instead he focuses on whether she could have changed the appointment.

As White describes, the bureaucratization of welfare means underlying assumptions and values "have been 'legalized', or reformulated as systems of explicit rules and values have been translated into a uniform currency or 'monetized'" (1990, 40). This reformulation is reductive; it leaves no room for the values and judgments underlying the rules. Cindy knows she is being judged by these larger values, but the rules prevent her from addressing them. She knows that at stake is more than her willingness to change her appointment, and that underlying the hearing officer's question are assumptions and stereotypes about Cindy as a welfare client. But the hearing room is not a place where Cindy can speak to this.

As Conley and Barr (1990) have found, relational testimony, such as Cindy's, which emphasizes the social rather than the legal, is more common 
among women, minorities, and the poor. The powerless and the victimized will look for an authoritative and understanding listener who will recognize the seriousness of their problem and use the law to right it. Since such clients are appealing to broader notions of need and justice, their accounts are similarly broad. To locate their problem in the larger world, they include the details of that world, including the extralegal. Under welfare reform, this need has grown even greater as clients' behaviors, rather than need, have become the welfare bureaucracy's central focus. The law, implicitly and explicitly, assumes welfare recipients are lazy and irresponsible. Thus, for clients, proving their moral worth and challenging the deeply rooted negative assumptions that construct the law are crucial and relevant. But while the procedural dictates of due process include the opportunity to be heard, this opportunity is as constricted as the law itself. Clients can address only the narrow legalistic terms of the law and not its underlying assumptions and values.

\section{CONCLUSION}

Our political and legal culture celebrates notions such as due process and procedural justice. The "opportunity to be heard" has an almost sacrosanct and hallowed timbre; it implies all have an opportunity to participate in the legal and political institutions that govern our lives. For the welfare poor, the Supreme Court decision in Kelly and its requirement of pretermination hearings was supposed to ensure their participation in the welfare bureaucracy, arguably the most significant government institution in their lives.

As this research demonstrates, the procedures spawned by Kelly are often an ill-fitting vessel for many welfare recipients. While standards of proof are technically the same for both agency and clients, clients are often presumed less credible. Most welfare recipients do not have the power to command the proof they need. They are often outmatched by their opponents, who, by the force and velocity of their questions, can quickly transform the hearing into an interrogation. The stories clients want to tell are not the ones hearing officers want to hear. The language clients speak is at odds with the language of law.

Despite this, some clients persevere, and ask for hearings. Like many citizens, they are as concerned with being heard by their governmental institutions as they are with the outcome of their case (Tyler 2006). Shut out below, they hope to find within the machinery of government a forum where they can obtain recompense and respect. They know the odds are against them, and that the law will not rescue them, but they also know that "the discourse of need and rules occur on law's terrain" (Sarat 1990, 374). Clients use fair hearings to engage, play with, and resist the law, hoping 
that it will protect them from an often arbitrary and capricious bureaucracy. The law, and fair hearings, is one tool-albeit an imperfect one-that sometimes can be used to resist the welfare bureaucracy.

Thus, fair hearings can't simply be dismissed as a useless artifact of the era of rights, poorly tailored then, and especially unsuitable now, in this era of welfare reform. Arguably, welfare reform has made fair hearings more, not less, essential. While subjective notions of worthiness have always influenced the distribution of aid, welfare reform has more deeply embedded this process in the law, using legal mechanisms, such as sanctions, to sort the worthy from the unworthy. Sanctions have enhanced the power of workers, whose imperfect sorting process rests on both rules and discretion. Fair hearings provide a forum for challenging decisions that are guided by this uneasy mix of discretion and rules. It permits closer scrutiny of workers' often subjective decisions about a client's willingness to work, and their application of the rules. ${ }^{11}$

However, changes are needed for fair hearings to succeed as a forum where client/citizens are fully and fairly heard. One tempting change is to ensure more lawyers for the poor in the hearing room. Like the impetus underlying Kelly, fighting law with law is one way to deal with a bureaucracy organized around law. Although most of the clients went to their hearing without a lawyer, they often identified a need for one. Lawyers, they were convinced, had access to evidentiary proof denied them as clients. They forced hearing officers and agency representatives to engage more fully in the facts and law of the case. They knew things clients, even those versed in the bureaucracy, didn't know.

But adding more lawyers, while helpful, does not ultimately tackle the underlying imbalance and fissures in the hearing room between clients and the hearing officer who judges them and the agency representatives who question them. Hearing officers and agency representatives are steeped in the language, social attitudes, and normative practices of the welfare bureaucracy. It is almost impossible for them to escape it, to step back and listen to and understand what the client is saying. Hearing officers often also abdicate their role, letting the agency representative, in essence, conduct the hearing. One way to disrupt this dynamic would be to physically remove fair hearings from the welfare center. ${ }^{12}$ The tie between the state and local agency could also be cut by using hearing officers not located within that system. White suggests that hearing officers should "share the perspective- the social locationof the claimant, particularly in a context like welfare hearings where the

11. Four out of five clients in New York City are successful at hearings challenging the application of work rules, thus demonstrating that hearings can be a useful tool for challenging agency decisions (Lens 2005).

12. These, and other changes such as rotating hearing officers to discourage familiarity with agency representatives, were suggested in a 1999 report by the New York State Bar Association based on a study of state agency administrative appeal proceedings. 
claimant is likely to come from a marginalized social group" $(1990,55)$. This might mean recruiting a different type of hearing officer, outside the state bureaucracy, including hearing officers that are part of clients' community or social class (White 1990).

White also suggests that hearing officers be trained to listen more closely and deeply to the speech of the powerless and intervene to restate it. Standards of proof and relevance could also be expanded to incorporate clients more relational style. Such changes would subtly subvert the hierarchy of power embedded in the bureaucracy. Instead of clients adapting to the bureaucracy, it would adapt to clients. This might make the hearing room a more comfortable and useable space for clients. To be sure it would not change the rules, nor the values and assumptions about clients underlying them. But it may provide more spaces within the law for clients to resist and be understood in their resistance.

\section{REFERENCES}

Anderson, Steven G., Anthony P. Halter, and Brian M. Gryzlak. 2004. Difficulties after Leaving TANF: Inner-City Women Talk about Reasons for Returning to Welfare. Social Work 49 (2): 185-94.

Bane, Mary Jo, and David T. Ellwood. 1994. Welfare Realities: From Rhetoric to Reform. Cambridge, MA: Harvard University Press.

Baum, Daniel. 1974. The Welfare Family and Mass Administrative Justice. New York: Praeger Publishers.

Bell, Alexander W., and Todd Norvell. 1967. Texas Welfare Appeals: The Hidden Right. Texas Law Review 46:223-53.

Bumiller, Kristin. 1987. Victims in the Shadow of the Law: A Critique of the Model of Legal Protection. Signs: Journal of Women in Culture EB Society 12 (3): 421-39.

Conley, John M., and William M. O’Barr. 1990. Rules Versus Relationships: The Ethnography of Legal Discourse. Chicago: University of Chicago Press.

Ewick, Patricia, and Susan S. Silbey. 1998. The Common Place of Law: Stories From Everyday Life. Chicago: University of Chicago Press.

Gilliom, John. 2001. Overseers of the Poor: Surveillance, Resistance, and the Limits of Privacy. Chicago: University of Chicago Press.

Hammer, Ronald P., and Joseph M. Hartley. 1978. Procedural Due Process and the Welfare Recipient: A Statistical Study of AFDC Fair Hearings in Wisconsin. Wisconsin Law Review 1:145-251.

Handler, Joel F. 1969. Justice for the Welfare Recipient: Fair Hearings in AFDC-The Wisconsin Experience. Social Service Review 4:12-34.

- 1986. The Conditions of Discretion: Autonomy, Community, Bureaucracy. New York: Russell Sage Foundation.

Kornbluh, Felicia. 2007. The Battle over Welfare Rights: Poverty and Policy in Modern America. Philadelphia: University of Pennsylvania Press.

Lens, Vicki. 2005. Bureaucratic Disentitlement After Welfare Reform: Are Fair Hearings the Cure? Georgetown Journal on Poverty Law and Policy 12 (1): 13-54.

—. 2006. Work Sanctions under Welfare Reform: Are They Helping Women Achieve Self-Sufficiency? Duke Journal of Gender Law and Policy 13:255-84. 
—. (forthcoming). Administrative Justice in Public Welfare Bureaucracies: When Citizen's (Don't) Complain. Administration $\mathcal{E}$ Society.

Mashaw, Jerry. 1973-74. The Management Side of Due Process: Some Theoretical and Litigation Notes on the Assurance of Accuracy, Fairness and Timeliness in the Adjudication of Social Welfare Claims. Cornell Law Review 59:772-824.

Miles, Matthew, and Michael Huberman. 1994. Qualitative Data Analysis. Thousand Oaks, CA: Sage Publications.

Miller, Gale. 1983. Holding Clients Accountable. Social Problems 31:139-51.

Miller, Gale, and James A. Holstein. 1996. Dispute Domains and Welfare Claims: Conflict and Law in Public Bureaucracies. Greenwich, CT: JAI Press Inc.

New York State Bar Association. October 21, 1999. Report of the Special Committee on Administrative Adjudication. Albany: New York State Bar Association.

Reich, Charles A. 1964. The New Property. Yale Law Journal 73:733-87.

Sarat, Austin. 1990. "The Law is All Over": Power, Resistance and the Legal Consciousness of the Welfare Poor. Yale Journal of Law $\mathcal{E}$ Humanities 2:343-79.

Sarat, Austin, and Thomas R. Kearns, eds. 1998. Beyond the Great Divide: Forms of Legal Scholarship and Everyday Life. In Law in Everyday Life. Ann Arbor: University of Michigan Press.

Scanlan, Melissa Kwaterski. 1998. The End of Welfare and Constitutional Protections for the Poor: A Case Study of the Wisconsin Works Program and Due Process Rights. Berkeley Women's Law Journal 13:153-94.

Simon, William. 1983. Legality, Bureaucracy and Class in the Welfare System. Yale Law Journal 92:1198-1269.

Soss, Joe. 2002. Unwanted Claims: The Politics of Participation in the U.S. Welfare System. Ann Arbor: The University of Michigan Press.

- 2005. Making Clients and Citizens: Welfare Policy as a Source of Status, Belief and Action. In Deserving and Entitled: Social Constructions and Public Policy, ed. Anne L. Schneider and Helen M. Ingram. Albany: State University of New York Press.

Strauss, Anselm. 1987. Qualitative Analysis for Social Scientists. Cambridge: Cambridge University Press.

Tyler, Tom. 2006. Why People Obey the Law. Princeton, NJ: Princeton University Press. White, Lucie E. 1990. Subordination, Rhetorical Survival Skills, and Sunday Shoes: Notes on the Hearing of Mrs. G. Buffalo Law Review 38 (1): 1-58.

\section{CASES CITED}

Goldberg v. Kelly, 397 U.S. 254 (1970).

Personal Responsibility and Work Opportunity Reconciliation Act of 1996, Pub. L. No. 104-193, 110 Stat. 2105 (codified at 42 U.S.C. $§ \S 601-19$ (1997)).

\section{STATUTES CITED}

42 U.S.C. Sec. 402 